\section{A new species of the genus Ectendomeliola (Meliolaceae) from Kerala, India}

\author{
V.B. Hosagoudar ${ }^{1} \&$ G.R. Archana ${ }^{2}$ \\ 1,2 Tropical Botanic Garden and Research Institute, Palode, \\ Thiruvananthapuram, Kerala 695562, India \\ Email: ${ }^{1}$ vbhosagoudar@rediffmail.com
}

The order Meliolales comprises two families: Meliolaceae and Armatellaceae with genera: Amazonia, Appendiculella, Asteridiella, Irenopsis, Meliola (Hansford 1961), Endomeliola (Hughes \& Pirozynski 1994), Pauhia (Stevens 1925; Hughes 1995), Prataprajella (Hosagoudar 1992), Armatella (Hosagoudar 1991, 2001), Basavamyces (Biju et al. 2005) and Ectendomeliola (Hosagoudar \& Agarwal 2006). Perithecium (flattened, globose or globose), setae (Perithecial or mycelial), appendages (horizontally striated projections from the perithecial wall cells) and the ascospore septation play an important role in generic segregation. All these 11 genera are represented by 2492 taxa (Hansford 1961; Hosagoudar et al. 1997; Hosagoudar \& Agarwal 2008).

These fungi are host specific or family specific (Hansford 1961). This hypothesis has been worked out by Goos (1978) on one occasion and appears to be adequate because they interact with the living cells of the plants. This biotrophic process interaction requires specific physiological and molecular interactions (Rodriguez \& Pipenbring 2007). Based on the monograph by Hansford (1961) and the subsequent regional floras (Hosagoudar 1996, 2008), Mibey \& Hawksworth (1997),

Date of publication (online): 26 July 2010

Date of publication (print): 26 July 2010

ISSN 0974-7907 (online) | 0974-7893 (print)

Editor: Richard Mibey

Manuscript details:

Ms \# 02464

Received 24 May 2010

Final revised received 12 July 2010

Finally accepted 13 July 2010

Citation: Hosagoudar, V.B. \& G.R. Archana (2010). A new species of the genus Ectendomeliola (Meliolaceae) from Kerala, India. Journal of Threatened Taxa 2(8): 1092-1095.

Copyright: ( ) V.B. Hosagoudar \& G.R. Archana 2010. Creative Commons Attribution 3.0 Unported License. JoTT allows unrestricted use of this article in any medium for non-profit purposes, reproduction and distribution by providing adequate credit to the authors and the source of publication.

Acknowledgements: We are thankful to Dr. A. Subramoniam, Director Tropical Botanic Garden and Research Institute, Palode for the facilities.

OPEN ACCESS | FREE DOWNLOAD (c) (1) (4)
Hu et al. (1996, 1999), India hosts the highest number (more than 600 taxa) of Meliolaceae members (Hosagoudar 1996, 2008).

\section{Otonephelium stipulaceum}

(Bedd.) Radlk. (Sapindaceae), an endemic plant to the Western Ghats region of Karnataka, Tamil Nadu and Kerala (Nayar et al. 2006), is subjected to infection from several parasitic fungi such as Meliola otonephelii, Asterostomella otonephelii, etc. During our study on foliicolous fungi of Western Ghats of Kerala State, this endemic plant collected from Moozhiyar forest of Pathanamthitta District was found infected with black mildew fungus. Microscopic examination of the fungus revealed its brown mycelium having both ectophytic and endophytic appressoria. This is the character of the genus Ectendomeliola of the family Meliolaceae (Hosagoudar \& Agarwal 2006, 2008; Hosagoudar 2008). This genus was known only with a single species, E. walsurae Hosag. \& Agarwal and the present collection is a second species of the genus.

Materials and Methods: Infected plant parts were selected in the field, field notes were made regarding their pathogenicity, nature of colonies, nature of infection and the collection locality. For each collection, a separate field number was given. In the field, each infected plant was collected separately in polythene bags along with the host twig (preferably with the reproductive parts to facilitate the identity of the corresponding host). These infected plant parts were pressed neatly and dried between blotting papers. After ensuring their dryness, they were used for microscopic study. Scrapes were taken directly from the infected host and mounted in $10 \% \mathrm{KOH}$ solution. After $30 \mathrm{~min}, \mathrm{KOH}$ was replaced by Lactophenol. Both the mountants work well as clearing agents and made the septa visible for taking measurements.

To study the entire colony in its natural condition, a drop of high quality natural coloured or well transparent nail polish, without gilt, was applied to the selected colonies and carefully thinned with the help of a fine brush without disturbing the colonies. Colonies with hyper parasites showing a woolly nature were avoided. The treated colonies along with their host plant were kept in dust free chamber for half an hour. When the nail polish on the colonies dried fully, a thin, colourless or slightly apple rose coloured (depending upon the colour tint in the nail polish) film or flip was formed with the colonies firmly embedded in it. In case of soft host parts, the flip was lifted off with a slight pressure on the opposite side of the leaves and just below the colonies. In the case of hard host parts, the flip was eased off with the help of a razor or scalpel. A drop of DPX was spread on a clean slide and the flips were spread properly on it. One or two more drops of DPX were added additionally on the flip and a clean cover glass was placed over it. By gently pressuring on the 
cover glass, excessive amount of DPX was removed after drying. Care was taken to avoid air bubbles. These slides were labeled and placed in a dust free chamber for one to two days for drying. These permanent slides were then used for further studies. Free hand sections were taken to study the endophytic appressoria.

\section{Ectendomeliola otonephelii sp. nov.}

(Fig. 1, Image 1)

Materials examined: 14.xii.2007, on leaves of Otonephelium stipulaceum (Sapindaceae), Moozhiyar forest, Patanamthitta, Kerala, India, coll. V. Gireesh Kumar et al TBGT 3941 (holotype), (MycoBank \# 518657).

This species differs from $E$. walsurae in having longer mycelial setae and larger Perithecia.

Coloniae hypophyllae, subdensae, crustosae, ad $4 \mathrm{~mm}$ diam., saepe confluentes. Hyphae subrectae vel anfractuae, irregulariter acuteque ramosae, formans irregulariter rete myceliales, laxe vel arte reticulatae, cellulae nodosae vel protuberentiae, 11-29 x 4-7 $\mu \mathrm{m}$. Appressoria ectophytica vel endophytica, appressoria innata intra-epidermalis, saepe in cellulae mesophyllis, bicellulae, 11-24 $\mu \mathrm{m}$ longae; cellulae basilares cylindraceae vel cuneatae, 3-8 $\mu \mathrm{m}$ longae; cellulae apicales ovatae, globosae, oblongae, integrae vel angularis, 8-16 x 6-8 $\mu \mathrm{m}$. Phialides paucae, mixtus appressoriis, oppositae, ampulliformes, 9-22 x 6-8 $\mu \mathrm{m}$. Setae myceliales numerosae, simplices, rectae vel uncinatae, acutae, obtusae, dentatae vel furcatae ad apicem, ad $412 \mu \mathrm{m}$ longae. Perithecia superficialis, dispersa vel aggregata, globosa, ostiolata, ad 126 $\mu \mathrm{m}$ diam.; ascosporae oblongae, cylindraceae, rectae vel leniter curvulae, 4-septatae, constrictus ad septatus, 35-42 x 11-15 $\mu \mathrm{m}$.

Colonies hypophyllous, subdense, crustose, up to $4 \mathrm{~mm}$ in diameter, often confluent. Hyphae substraight to crooked, branching irregular at acute angles, form irregular mycelial net, loosely to closely reticulate, cells

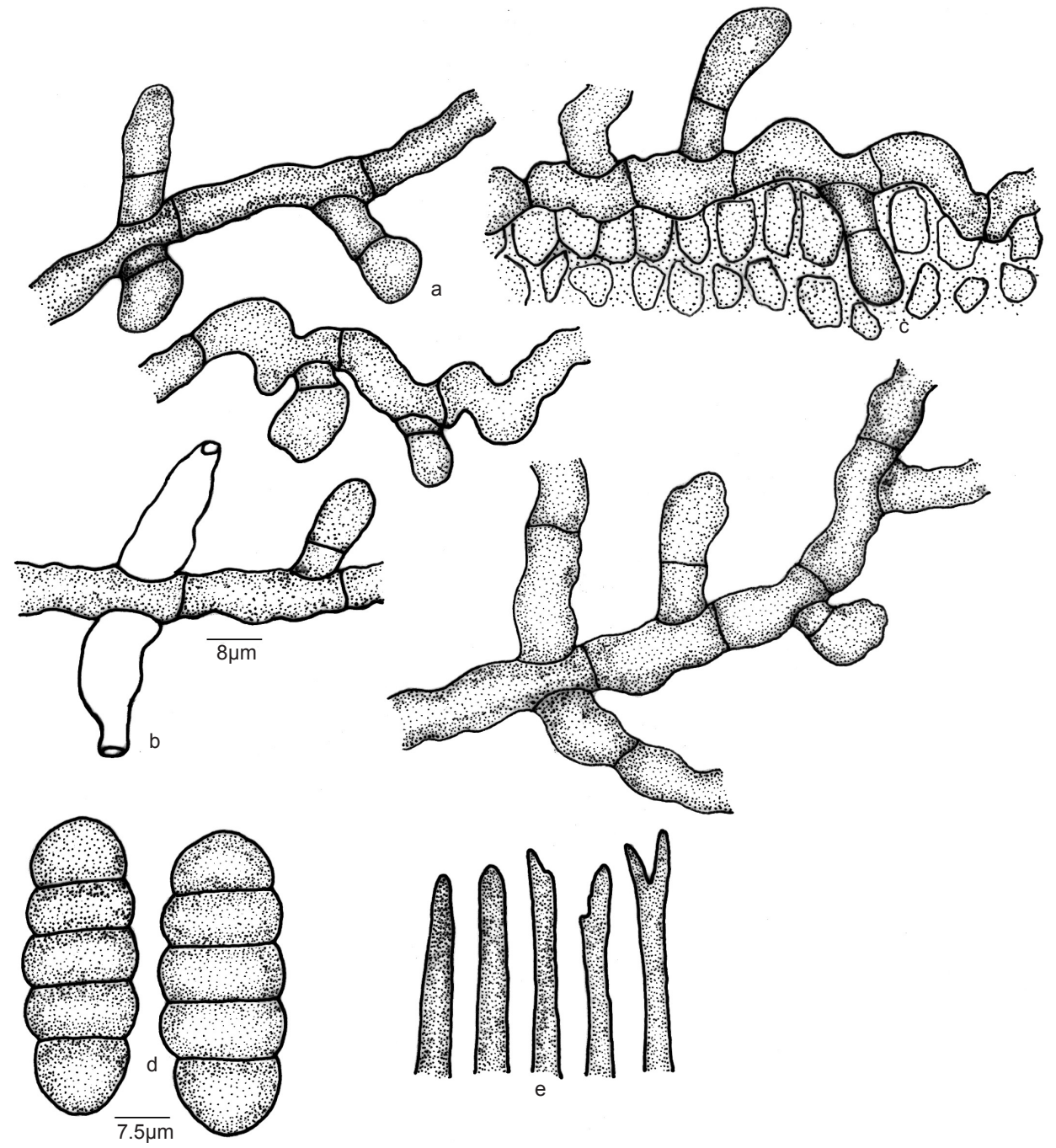

Figure 1. Ectendomeliola otonephelii sp. nov.

a - Appressorium; b - Phialide; c - Apical portion of the mycelial setae; $d$ - Ascospores; e - Innate appressorium 

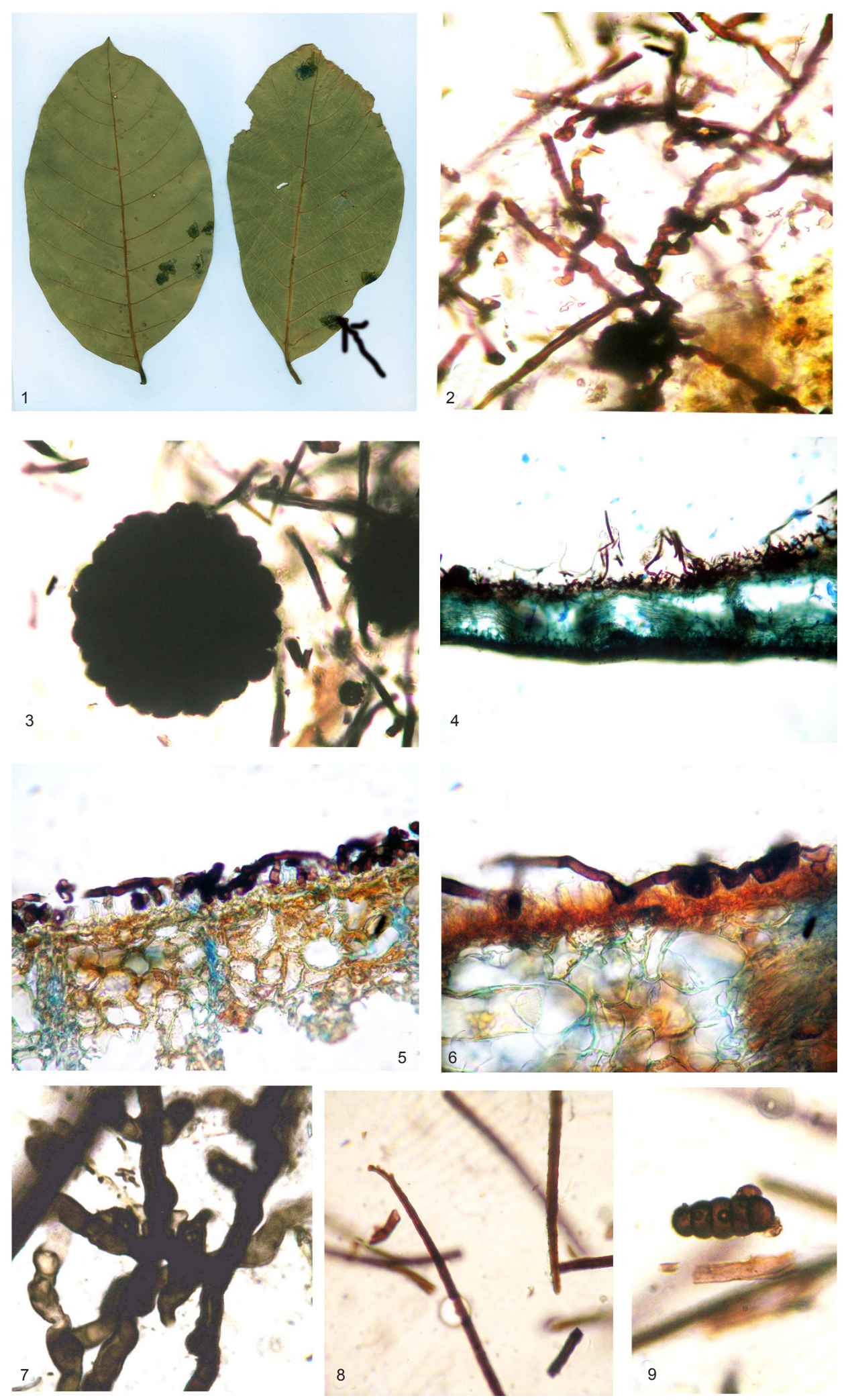

Image 1. Ectendomeliola otonephelii sp. nov.

1 - Hypophyllous colonies on the leaves; 2 - Crooked mycelium with appressoria with an intermitant mycelial knot; 3 - Perithecium; 4 - T.S. showing the arrangement of mycelium and appressoria;

5 - Subepidermal appressoria; 6 - Mycelium, appressorium and initials of perithecia; 7 - Phialides on the mycelium; 8 - Apical tip of mycelial setae; 9 - Ascospore 
beaded to bulged, 11-29 x 4-7 $\mu \mathrm{m}$. Appressoria ectophytic and endophytic, innate appressoria intra-epidermal, often in mesophyll cells, two celled, 11-24 $\mu \mathrm{m}$ long; stalk cells cylindrical to cuneate, 3-8 $\mu \mathrm{m}$ long; head cells ovate, globose, oblong, entire to angular, 8-16 $\times 6-8 \mu \mathrm{m}$. Phialides few, mixed with appressoria, opposite, ampulliform, 9-22 x 6-8 $\mu \mathrm{m}$. Mycelial setae numerous, simple, straight to uncinate, acute, obtuse, dentate to furcate at the tip, up to $412 \mu \mathrm{m}$ long. Perithecia superficial, scattered to grouped, globose, ostiolate, up to $126 \mu \mathrm{m}$ in diameter; ascospores oblong, cylindrical, straight to slightly curved, 4-septate, constricted at the septa, 35-42 x 11-15 $\mu \mathrm{m}$.

\section{REFERENCES}

Goos, R.D. (1978). Field and laboratory studies of meliolaceous fungi in Hawaii. Mycologia 70: 995-1006.

Hansford, C.G. (1961). The Meliolineae. A Monograph. Sydowia Beih 2: 1-806.

Hosagoudar, V.B. (1991). The genus Armatella (P.Henn.) Theiss. \& Sydow (Meliolaceae) in India. Journal of Economic and Taxonomic Botany 15: 195-202.

Hosagoudar, V.B. (1992). Prataprajella, a new genus of the family Meliolaceae. Nova Hedwigia 55: 223-226.

Hosagoudar, V.B. (1996). Meliolales of India. Botanical Survey of India, Calcutta, 363pp.

Hosagoudar, V.B. (2008). Meliolales of India. Vol. II. Botanical Survey of India, Calcutta, 390pp.

Hosagoudar, V.B. \& T.K. Abraham (2001). A literature survey of the genus Armatella (P. Henn.) Theiss. \& Sydow
(Meliolaceae). Journal of Economic and Taxonomic Botany 25: $560-568$

Hosagoudar, V.B. \& D.K. Agarwal (2008). Taxonomic studies of Meliolales. Identification Manual. International Book Distributors, Dehra Dun, 263pp.

Hosagoudar, V.B., T.K. Abraham \& P. Pushpangadan (1997). The Meliolineae - A Supplement. Tropical Botanic Garden and Research Institute, Palode, Thiruvananthapuram, Kerala, India, 201pp.

Hosagoudar, V.B. \& D.K. Agarwal (2006). Ectendomeliola, a new genus of the family Meliolaceae. Indian Phytopathology 59: 98-100.

Hosagoudar, V.B., T.K. Abraham \& C.K. Biju (2001). Meliolaceae of Kerala, India - IX. Journal of Economic and Taxonomic Botany 25: 553-559.

Hu, Y.X., Y.S. Ouyang, B. Song \& G.Z. Jiang (1996). Flora Fungorum Sinicorum. Vol. 4. Meliolales. Science Press, Beijing, 270pp.

Hu, Y.X., Y.S. Ouyang, B. Song \& G.Z. Jiang (1999). Flora Fungorum Sinicorum. vol.II. Meliolales II. Science Press, Beijing, 218pp.

Hughes, S.J. (1995). Pauhia, a new genus of Meliolineae. Mycologia 87: 702-706.

Hughes, S.J. \& K.A. Pirozynski (1994). New Zealand fungi-34 Endomeliola dingleyae, a new genus and new species of Meliolaceae. New Zealand Journal of Botany 32: 53-59.

Mibey, R.K. \& D.L. Hawksworth (1997). Meliolaceae and Asterinaceae of the Shimba Hills, Kenya. Mycological Papers 174: 1-108.

Nayar, T.S., A.R. Beegam, N. Mohanan \& G. Rajkumar (2006). Flowering plants of Kerala-A hand book. Tropical Botanic Garden and Research Institute, Thiruvananthapuram, Kerala.

Stevens, F.L. (1925). Hawaiian fungi. Bernice P. Bishop Museum Bulletin 19: 1-189. 